The treatment option for cancers of the tongue is glossectomy, which may be partial, sub-total, or total, depending on the size of the tumour. Glossectomies result in speech deficits for these patients, and rehabilitative therapy involving communication modalities is highly recommended. Sign language is a possible therapeutic solution for post-glossectomy oral cancer patients. Patients with tongue cancers who have undergone total glossectomy as a surgical treatment can utilise sign language to replace their loss of speech production and maintain their engagement in life. This manuscript emphasises the importance of sign language in rehabilitation strategies in post-glossectomy patients.

Key words: tongue, cancer, glossectomy, sign language, rehabilitation.

Contemp Oncol (Pozn) 2014; 21 (2): 123-130 DOI: https://doi.org/10.5114/wo.2017.68620

\section{Post-glossectomy in lingual carcinomas: a scope for sign language in rehabilitation}

\author{
Arvind Babu Rajendra Santosh ${ }^{1}$, Keren Cumberbatch ${ }^{2}$, Thaon Jones ${ }^{1}$
}

${ }^{1}$ Dentistry Programme, Faculty of Medical Sciences, The University of the West Indies, Mona Campus, Kingston, Jamaica, West Indies

${ }^{2}$ Department of Language, Linguistics and Philosophy, Faculty of Humanities and Education; Deaf Clinic, Faculty of Medical Sciences, The University of the West Indies, Mona Campus, Kingston, Jamaica, West Indies

\section{Introduction}

Oral cancers are the seventh most common cancer of the body. Among the oral cancers, squamous cell carcinoma is the most common. Squamous cell carcinoma can affect the lips, cheek mucosa, tongue, palate or teeth-bearing alveolar segment, and gums. Cancers like squamous cell carcinoma are widely treated with the surgical option of excision of the involved tissue. In instances of cancer of the tongue, the affected tongue areas are excised and this results in compromising the speech skills of these patients. Communication therapy is highly recommended for these individuals.

Speech has an oral-aural mode because it is orally produced and aurally perceived. Having lost the ability to speak, these patients often resort to note writing or pantomime to express themselves. Sign language, given its visual-gestural modality, is ideal as a means of communication for persons who cannot produce speech. Post-glossectomy patients can perceive speech auditorily and respond using signs to produce the same level of lexical and grammatical complexity found in speech.

The aim of this review is to propose sign language as a communication solution for post-glossectomy oral cancer patients. The focal point of this article is to show how patients with tongue cancers who have undergone total glossectomy as a surgical treatment can use sign language to replace their loss of speech production.

\section{Literature review}

A literature search for glossectomy procedures on tongue cancer cases was conducted in the PubMed database using the Medical Subject Heading (MeSH) term "glossectomy and tongue cancer" from the late 1980s to 2015. Four hundred and thirty-one research papers were found. The inclusion criteria were: 1) free full-text availability, 2) English language, and 3) glossectomy, tongue cancer and speech difficulty. The exclusion criteria were duplicated titles, and incorrect web-link for full text accessibility. These criteria resulted in 39 free full text papers being included (Fig. 1). The study designs, titles, abstracts, results and discussions in the 39 research papers were reviewed. Following this review, 24 research papers were excluded due to lack of information on speech difficulty. The review process yielded 15 research papers which have been considered in the present paper that satisfied the inclusion criteria (Table 1).

Luna Ortiz et al. reported that speech difficulties in tongue cancer patients are related to the size of the tumour [1]. Slurred speech is also reported in tongue cancer patients [2]. Murano et al. in 2010 reported that post-partial glossectomy with selective neck dissection resulted in numbness of the tongue, but no swallowing or speech problems [3]. Research results on 
Table 1. Summary of case report and research studies on speech difficulty in glossectomy patients

\begin{tabular}{|c|c|c|c|c|c|c|}
\hline Author & Tongue cancer type & $\begin{array}{l}\text { Glossectomy and } \\
\text { other treatment } \\
\text { details }\end{array}$ & $\begin{array}{l}\text { Number } \\
\text { of study } \\
\text { population }\end{array}$ & $\begin{array}{l}\text { Design/ } \\
\text { Reporting } \\
\text { country }\end{array}$ & $\begin{array}{l}\text { Reporting } \\
\text { speciality }\end{array}$ & Results/ comments \\
\hline $\begin{array}{l}\text { Chung et al. } \\
2015[18]\end{array}$ & Lingual tumour & Partial glossectomy & 1285 & $\begin{array}{l}\text { Research study, } \\
\text { United States }\end{array}$ & Otolaryn-gology & Speech difficulty not reported \\
\hline $\begin{array}{l}\text { Saxena et al. } \\
1970[19]\end{array}$ & Lingual carcinomas & $\begin{array}{l}\text { Radiotherapy, } \\
\text { subsequent surgery } \\
\text { and radiotherapy }\end{array}$ & 456 & $\begin{array}{l}\text { Research study, } \\
\text { Canada }\end{array}$ & $\begin{array}{l}\text { Radiation } \\
\text { therapy }\end{array}$ & Speech difficulty not reported \\
\hline $\begin{array}{l}\text { Toshifumi et } \\
\text { al. } 2013 \text { [20] }\end{array}$ & $\begin{array}{l}\text { Squamous cell } \\
\text { carcinoma of the } \\
\text { tongue (Clinical } \\
\text { stage I and II) }\end{array}$ & Partial glossectomy & 365 & $\begin{array}{l}\text { Research study, } \\
\text { Japan }\end{array}$ & $\begin{array}{l}\text { Head and neck } \\
\text { surgery }\end{array}$ & Speech difficulty not reported \\
\hline $\begin{array}{l}\text { Mizuo et al. } \\
2009[21]\end{array}$ & $\begin{array}{l}\text { Squamous cell } \\
\text { carcinoma of the } \\
\text { tongue }\end{array}$ & Glossectomy & 248 & $\begin{array}{l}\text { Research study, } \\
\text { Tokyo }\end{array}$ & $\begin{array}{l}\text { Head and neck } \\
\text { surgery }\end{array}$ & Speech difficulty not reported \\
\hline $\begin{array}{l}\text { Ganly et al. } \\
2013 \text { [22] }\end{array}$ & $\begin{array}{l}\text { Squamous cell } \\
\text { carcinoma of the } \\
\text { tongue }\end{array}$ & $\begin{array}{l}\text { Partial glossectomy } \\
\text { and neck } \\
\text { dissection without } \\
\text { postoperative } \\
\text { radiation }\end{array}$ & 164 & $\begin{array}{l}\text { Research study, } \\
\text { United States }\end{array}$ & $\begin{array}{l}\text { Head and neck } \\
\text { surgery }\end{array}$ & Speech difficulty not reported \\
\hline $\begin{array}{l}\text { Parikh et al. } \\
1998 \text { [6] }\end{array}$ & $\begin{array}{l}\text { Squamous cell } \\
\text { carcinoma of the } \\
\text { tongue }\end{array}$ & $\begin{array}{l}\text { Hemiglossectomy } \\
\text { or total glossectomy }\end{array}$ & 126 & $\begin{array}{l}\text { Research study, } \\
\text { India }\end{array}$ & $\begin{array}{l}\text { Head and neck } \\
\text { surgery }\end{array}$ & $\begin{array}{l}\text { 1. Glossectomy procedures have } \\
\text { considerable speech difficulties } \\
\text { 2. No difference in the quality } \\
\text { of speech between the two types } \\
\text { of surgery }\end{array}$ \\
\hline $\begin{array}{l}\text { Urashima et } \\
\text { al. } 2006 \text { [23] }\end{array}$ & $\begin{array}{l}\text { Squamous cell } \\
\text { carcinoma in } \\
108 \text { patients, } \\
\text { Muco-epidermoid } \\
\text { carcinoma in } \\
2 \text { patients, Adenoid } \\
\text { cystic carcinoma in } \\
1 \text { patient }\end{array}$ & $\begin{array}{l}\text { Brachytherapy } \\
\text { with or without } \\
\text { chemotherapy and } \\
\text { radiotherapy }\end{array}$ & 111 & $\begin{array}{l}\text { Research study, } \\
\text { Japan }\end{array}$ & Clinical radiology & Speech difficulty not reported \\
\hline $\begin{array}{l}\text { Halczy- } \\
\text {-Kowalik et al. } \\
2012[7]\end{array}$ & Lingual tumour & $\begin{array}{l}\text { Hemi/partial/total- } \\
\text { glossectomy }\end{array}$ & 95 & $\begin{array}{l}\text { Research } \\
\text { study/Poland }\end{array}$ & $\begin{array}{l}\text { Post-operative } \\
\text { rehabilitation } \\
\text { in oral and } \\
\text { maxillofacial } \\
\text { surgery }\end{array}$ & $\begin{array}{l}\text { Reconstruction of the tongue mass } \\
\text { after a hemiglossectomy may be } \\
\text { beneficial for the act of swallowing } \\
\text { and detrimental for speech } \\
\text { generation because of the limited } \\
\text { mobility of the remaining part } \\
\text { of the tongue }\end{array}$ \\
\hline $\begin{array}{l}\text { Akhtar et al. } \\
2007[24]\end{array}$ & $\begin{array}{l}\text { Squamous cell } \\
\text { carcinoma of the } \\
\text { tongue }\end{array}$ & $\begin{array}{l}\text { Partial glossectomy } \\
\text { and an elective } \\
\text { modified radical } \\
\text { neck dissection }\end{array}$ & 94 & $\begin{array}{l}\text { Research study, } \\
\text { Pakistan }\end{array}$ & Otolaryngology & Speech difficulty not reported \\
\hline $\begin{array}{l}\text { Ikram et al. } \\
2006[25]\end{array}$ & $\begin{array}{l}\text { Squamous cell } \\
\text { carcinoma of the } \\
\text { tongue }\end{array}$ & $\begin{array}{l}\text { Hemiglossectomy } \\
\text { with or without } \\
\text { neck dissection and } \\
\text { radiotherapy }\end{array}$ & 80 & $\begin{array}{l}\text { Research study, } \\
\text { Pakistan }\end{array}$ & Otolaryngology & Speech difficulty not reported \\
\hline $\begin{array}{l}\text { Habu et al. } \\
\text { 2015) 26) }\end{array}$ & $\begin{array}{l}\text { Oral squamous cell } \\
\text { carcinoma (Clinical } \\
\text { stage I and II) }\end{array}$ & Partial glossectomy & 50 & $\begin{array}{l}\text { Research study, } \\
\text { Tokyo }\end{array}$ & $\begin{array}{l}\text { Otorhino- } \\
\text { laryngology }\end{array}$ & Speech difficulty not reported \\
\hline $\begin{array}{l}\text { López et al. } \\
2004 \text { [27] }\end{array}$ & $\begin{array}{l}\text { Squamous cell } \\
\text { carcinoma of the } \\
\text { tongue }\end{array}$ & Glossectomy & 46 & $\begin{array}{l}\text { Research study, } \\
\text { United States }\end{array}$ & Pathology & Speech difficulty not reported \\
\hline $\begin{array}{l}\text { Shiga et al. } \\
2012[28]\end{array}$ & $\begin{array}{l}\text { Squmaous cell } \\
\text { carcinoma of the } \\
\text { tongue ( } 42 \text { patients) } \\
\text { and Verrucous } \\
\text { carcinoma of the } \\
\text { tongue (1 patient) }\end{array}$ & $\begin{array}{l}\text { T1 cancer was } \\
\text { treated with partial } \\
\text { glossectomy with } \\
\text { or without neck } \\
\text { dissection. Late T2NO } \\
\text { tumours were treated } \\
\text { with Supra-Omohyoid } \\
\text { neck dissection. } \\
\text { Recurrent tumour }\end{array}$ & 43 & $\begin{array}{l}\text { Research study, } \\
\text { Japan }\end{array}$ & Otolaryngology & Speech difficulty not reported \\
\hline
\end{tabular}


Table 1. Cont.

\begin{tabular}{|c|c|c|c|c|c|c|}
\hline Author & Tongue cancer type & $\begin{array}{l}\text { Glossectomy and } \\
\text { other treatment } \\
\text { details }\end{array}$ & $\begin{array}{l}\text { Number } \\
\text { of study } \\
\text { population }\end{array}$ & $\begin{array}{l}\text { Design/ } \\
\text { Reporting } \\
\text { country }\end{array}$ & $\begin{array}{l}\text { Reporting } \\
\text { speciality }\end{array}$ & Results/ comments \\
\hline & & $\begin{array}{l}\text { with no prior neck } \\
\text { dissection at first } \\
\text { surgery an additional } \\
\text { surgery with neck } \\
\text { dissection was } \\
\text { done. When surgery } \\
\text { was not possible, } \\
\text { radiotherapy and } \\
\text { chemotherapy were } \\
\text { recommended }\end{array}$ & & & & \\
\hline $\begin{array}{l}\text { Tarsitano } \\
\text { et al. } \\
2013[8]\end{array}$ & Lingual tumour & $\begin{array}{l}\text { Hemiglossectomy, } \\
\text { chemotherapy and } \\
\text { radiotherapy }\end{array}$ & 26 & $\begin{array}{l}\text { Research study, } \\
\text { Italy }\end{array}$ & $\begin{array}{l}\text { Oral and } \\
\text { maxillofacial } \\
\text { surgery }\end{array}$ & $\begin{array}{l}\text { No significant differences were seen } \\
\text { for speech intelligibility or quality of } \\
\text { life between free radial forearm flap } \\
\text { and anterolateral thigh flap }\end{array}$ \\
\hline $\begin{array}{l}\text { Bachher et al. } \\
2002[11]\end{array}$ & Lingual tumour & Partial glossectomy & 25 & $\begin{array}{l}\text { Research study, } \\
\text { India }\end{array}$ & $\begin{array}{l}\text { Speech- } \\
\text { language } \\
\text { pathology }\end{array}$ & $\begin{array}{l}\text { 1. Voice quality and resonance are } \\
\text { compromised after surgery because } \\
\text { of changes in oral cavity volume } \\
\text { 2. Articulation is affected because } \\
\text { the tongue is unable to assume } \\
\text { the normal position to provide } \\
\text { valuing action needed for precise } \\
\text { articulation } \\
\text { 3. The larger the segment of the } \\
\text { tongue, the greater is the distortion } \\
\text { of speech }\end{array}$ \\
\hline $\begin{array}{l}\text { Pugazhendi } \\
\text { et al. } \\
2012[29]\end{array}$ & $\begin{array}{l}\text { Squamous cell } \\
\text { carcinoma of the } \\
\text { tongue (Clinical } \\
\text { stage I and II) }\end{array}$ & $\begin{array}{l}\text { Glossectomy with } \\
\text { and without neck } \\
\text { dissection }\end{array}$ & 21 & $\begin{array}{l}\text { Research study, } \\
\text { India }\end{array}$ & $\begin{array}{l}\text { Oral and } \\
\text { maxillofacial } \\
\text { surgery }\end{array}$ & Speech difficulty not reported \\
\hline $\begin{array}{l}\text { Sargis et al. } \\
2015 \text { [12] }\end{array}$ & $\begin{array}{l}\text { Squamous cell } \\
\text { carcinoma of the } \\
\text { tongue }\end{array}$ & $\begin{array}{l}\text { Glossectomy with } \\
\text { lingual lymph node } \\
\text { removal }\end{array}$ & 21 & $\begin{array}{l}\text { Research } \\
\text { study, } \\
\text { Moscow }\end{array}$ & $\begin{array}{l}\text { Oral and } \\
\text { maxillofacial } \\
\text { surgery }\end{array}$ & $\begin{array}{l}\text { Speech is believed to be } \\
\text { determined by variables as the } \\
\text { extent and the site of resection }\end{array}$ \\
\hline $\begin{array}{l}\text { Pons et al. } \\
2009 \text { [30] }\end{array}$ & $\begin{array}{l}\text { Squmaous cell } \\
\text { carcinoma of the } \\
\text { tongue }\end{array}$ & $\begin{array}{l}\text { Partial } \\
\text { glossectomy }\end{array}$ & 18 & $\begin{array}{l}\text { Research } \\
\text { study, France }\end{array}$ & $\begin{array}{l}\text { Head and neck } \\
\text { surgery }\end{array}$ & Speech difficulty not reported \\
\hline $\begin{array}{l}\text { Saito et al. } \\
1999 \text { [31] }\end{array}$ & Lingual tumour & Glossectomy & 16 & $\begin{array}{l}\text { Research } \\
\text { study, Japan }\end{array}$ & Anesthesia & Speech difficulty not reported \\
\hline $\begin{array}{l}\text { Urashima et } \\
\text { al. } 2006 \text { [23] }\end{array}$ & $\begin{array}{l}\text { Squamous cell } \\
\text { carcinoma of the } \\
\text { tongue }\end{array}$ & Glossectomy & 10 & $\begin{array}{l}\text { Research } \\
\text { study, Japan }\end{array}$ & $\begin{array}{l}\text { Oral and } \\
\text { maxillofacial } \\
\text { surgery }\end{array}$ & Speech difficulty not reported \\
\hline $\begin{array}{l}\text { Stone et al. } \\
2014 \text { [13] }\end{array}$ & Lingual tumour & $\begin{array}{l}\text { Partial } \\
\text { glossectomy } \\
\text { (Lateral tongue) }\end{array}$ & 10 & $\begin{array}{l}\text { Research } \\
\text { study, United } \\
\text { States }\end{array}$ & $\begin{array}{l}\text { Neural and } \\
\text { pain science }\end{array}$ & $\begin{array}{l}\text { In glossectomy patients, slight } \\
\text { differences in tumour size do not } \\
\text { create significant differences in } \\
\text { ability to produce speech gestures }\end{array}$ \\
\hline $\begin{array}{l}\text { Stone et al. } \\
2014 \text { [14] }\end{array}$ & $\begin{array}{l}\text { Squamous cell } \\
\text { carcinoma of the } \\
\text { tongue }\end{array}$ & $\begin{array}{l}\text { Partial } \\
\text { glossectomy }\end{array}$ & 3 & $\begin{array}{l}\text { Research } \\
\text { study, United } \\
\text { States }\end{array}$ & Dental & $\begin{array}{l}\text { Patients would have limited } \\
\text { motion on the tumour (resected) } \\
\text { side and would compensate with } \\
\text { greater motion on the non-tumour } \\
\text { side in order to elevate the tongue } \\
\text { tip and blade }\end{array}$ \\
\hline $\begin{array}{l}\text { Bell et al. } \\
2009 \text { [2] }\end{array}$ & $\begin{array}{l}\text { Colonic-type } \\
\text { adenocarcinomas } \\
\text { of the base of the } \\
\text { tongue }\end{array}$ & $\begin{array}{l}\text { Total glossectomy } \\
\text { with neck } \\
\text { dissection } \\
\text { (Unilateral/ } \\
\text { Bilateral) }\end{array}$ & 2 & $\begin{array}{l}\text { Case report, } \\
\text { United States }\end{array}$ & Pathology & $\begin{array}{l}\text { One patient had slurred speech } \\
\text { as an oral complaint while having } \\
\text { cancer }\end{array}$ \\
\hline $\begin{array}{l}\text { Esamti et al. } \\
2015 \text { [32] }\end{array}$ & $\begin{array}{l}\text { Poorly } \\
\text { differentiated } \\
\text { neuroendocrine } \\
\text { carcinoma }\end{array}$ & $\begin{array}{l}\text { Partial } \\
\text { glossectomy, } \\
\text { chemotherapy and } \\
\text { chemoradiation }\end{array}$ & 1 & $\begin{array}{l}\text { Case report, } \\
\text { Iran }\end{array}$ & $\begin{array}{l}\text { Radiation } \\
\text { oncology }\end{array}$ & Speech difficulty not reported \\
\hline
\end{tabular}


Table 1. Cont.

\begin{tabular}{|c|c|c|c|c|c|c|}
\hline Author & Tongue cancer type & $\begin{array}{l}\text { Glossectomy and } \\
\text { other treatment } \\
\text { details }\end{array}$ & $\begin{array}{l}\text { Number } \\
\text { of study } \\
\text { population }\end{array}$ & $\begin{array}{l}\text { Design/ } \\
\text { Reporting } \\
\text { country }\end{array}$ & $\begin{array}{l}\text { Reporting } \\
\text { speciality }\end{array}$ & Results/ comments \\
\hline $\begin{array}{l}\text { Tanaka } \\
\text { et al. } \\
2014[33]\end{array}$ & $\begin{array}{l}\text { Squamous cell } \\
\text { carcinoma of the } \\
\text { tongue }\end{array}$ & $\begin{array}{l}\text { Partial } \\
\text { glossectomy and } \\
\text { left selective neck } \\
\text { dissection }\end{array}$ & 1 & $\begin{array}{l}\text { Case report, } \\
\text { Japan }\end{array}$ & Otolaryngology & Speech difficulty not reported \\
\hline $\begin{array}{l}\text { Preetam et al. } \\
\text { 2013) [35] }\end{array}$ & Tongue carcinoma & $\begin{array}{l}\text { hemiglossectomy } \\
\text { and } \\
\text { supraomohyoid } \\
\text { dissection }\end{array}$ & 1 & $\begin{array}{l}\text { Case study, } \\
\text { India }\end{array}$ & $\begin{array}{l}\text { Otorhinola- } \\
\text { ryngology }\end{array}$ & Speech difficulty not reported \\
\hline $\begin{array}{l}\text { Crede et al. } \\
2012 \text { [36] }\end{array}$ & $\begin{array}{l}\text { Squamous cell } \\
\text { carcinoma of the } \\
\text { tongue }\end{array}$ & $\begin{array}{l}\text { Partial } \\
\text { glossectomy with } \\
\text { microvascular } \\
\text { reconstruction }\end{array}$ & 1 & $\begin{array}{l}\text { Case report, } \\
\text { Pakistan }\end{array}$ & $\begin{array}{l}\text { Oral and } \\
\text { maxillofacial } \\
\text { surgery }\end{array}$ & Speech difficulty not reported \\
\hline $\begin{array}{l}\text { Irfan et al. } \\
2011 \text { [37] }\end{array}$ & $\begin{array}{l}\text { Squamous cell } \\
\text { carcinoma of the } \\
\text { tongue }\end{array}$ & $\begin{array}{l}\text { Partial } \\
\text { glossectomy }\end{array}$ & 1 & $\begin{array}{l}\text { Case report, } \\
\text { Malaysia }\end{array}$ & $\begin{array}{l}\text { Otorhinola- } \\
\text { ryngology }\end{array}$ & Speech difficulty not reported \\
\hline $\begin{array}{l}\text { Deshmukh et } \\
\text { al. } 2011 \text { [38] }\end{array}$ & $\begin{array}{l}\text { Squamous cell } \\
\text { carcinoma of the } \\
\text { tongue (T1, N3 and } \\
\text { MO) }\end{array}$ & $\begin{array}{l}\text { Partial } \\
\text { glossectomy with } \\
\text { bilateral modified } \\
\text { neck dissection } \\
\text { was performed }\end{array}$ & 1 & $\begin{array}{l}\text { Case report, } \\
\text { India }\end{array}$ & Pathology & Speech difficulty not reported \\
\hline $\begin{array}{l}\text { McNamara } \\
\text { et al. } \\
2011[39]\end{array}$ & Hemangioma & $\begin{array}{l}\text { Partial } \\
\text { glossectomy }\end{array}$ & 1 & $\begin{array}{l}\text { Case report, } \\
\text { United } \\
\text { Kingdom }\end{array}$ & Otolaryngology & Speech difficulty not reported \\
\hline $\begin{array}{l}\text { Bhojraj } \\
\text { et al. } \\
2008[40]\end{array}$ & $\begin{array}{l}\text { Primary malignant } \\
\text { ulcer on the } \\
\text { tongue }\end{array}$ & $\begin{array}{l}\text { Glossectomy with } \\
\text { reconstruction }\end{array}$ & 1 & $\begin{array}{l}\text { Case report, } \\
\text { India }\end{array}$ & $\begin{array}{l}\text { Cardiac } \\
\text { anaesthesia }\end{array}$ & Speech difficulty not reported \\
\hline $\begin{array}{l}\text { Murano } \\
\text { et al. } \\
2010[3]\end{array}$ & $\begin{array}{l}\text { Squamous cell } \\
\text { carcinoma of the } \\
\text { tongue (T1, NO } \\
\text { and } \mathrm{MO})\end{array}$ & $\begin{array}{l}\text { Partial } \\
\text { glossectomy with } \\
\text { selective neck } \\
\text { dissection }\end{array}$ & 1 & $\begin{array}{l}\text { Case report, } \\
\text { United States }\end{array}$ & $\begin{array}{l}\text { Neural and } \\
\text { pain sciences }\end{array}$ & $\begin{array}{l}\text { After surgery, the patient reported } \\
\text { numbness of the right tongue, but } \\
\text { no swallowing or speech problems }\end{array}$ \\
\hline $\begin{array}{l}\text { Mazeron } \\
\text { et al. } \\
2013[4]\end{array}$ & $\begin{array}{l}\text { Isolated tongue } \\
\text { metastasis of } \\
\text { renal clear cell } \\
\text { carcinoma }\end{array}$ & Brachytherapy & 1 & $\begin{array}{l}\text { Case study, } \\
\text { France }\end{array}$ & Brachytherapy & $\begin{array}{l}\text { Brachytherapy limits the target } \\
\text { volume as compared to external } \\
\text { beam radiation, better protecting } \\
\text { the organ involved in speech }\end{array}$ \\
\hline $\begin{array}{l}\text { Unsworth } \\
\text { et al. } \\
2013[9]\end{array}$ & $\begin{array}{l}\text { Squamous cell } \\
\text { carcinoma of the } \\
\text { tongue }\end{array}$ & $\begin{array}{l}\text { Partial } \\
\text { glossectomy with } \\
\text { microvascular } \\
\text { reconstruction }\end{array}$ & 1 & $\begin{array}{l}\text { Case report, } \\
\text { United } \\
\text { Kingdom }\end{array}$ & Medicine & $\begin{array}{l}\text { Good oral function (speech and } \\
\text { swallowing) was restored within } \\
2 \text { weeks }\end{array}$ \\
\hline $\begin{array}{l}\text { Tasker et al. } \\
2005 \text { [5] }\end{array}$ & $\begin{array}{l}\text { Giant cavernous } \\
\text { hemangioma } \\
\text { of tongue }\end{array}$ & Total glossectomy & 1 & $\begin{array}{l}\text { Case report, } \\
\text { United } \\
\text { Kingdom }\end{array}$ & $\begin{array}{l}\text { Emergency } \\
\text { medicine }\end{array}$ & $\begin{array}{l}\text { Patient post-operative progress } \\
\text { was extremely good and at } \\
\text { discharge had intelligible speech }\end{array}$ \\
\hline $\begin{array}{l}\text { Kies et al. } \\
2012 \text { [15] }\end{array}$ & $\begin{array}{l}\text { Squamous cell } \\
\text { carcinoma of the } \\
\text { tongue }\end{array}$ & $\begin{array}{l}\text { Chemotherapy } \\
\text { followed by } \\
\text { glossectomy } \\
\text { and neck } \\
\text { dissection and/or } \\
\text { radiotherapy and } \\
\text { chemotherapy }\end{array}$ & 1 & $\begin{array}{l}\text { Research } \\
\text { study, United } \\
\text { States }\end{array}$ & $\begin{array}{l}\text { Thoracic/ } \\
\text { head and } \\
\text { neck medical } \\
\text { oncology }\end{array}$ & $\begin{array}{l}\text { Patients underwent a standardized } \\
\text { speech and swallowing evaluation } \\
\text { before induction chemotherapy } \\
\text { and after induction chemotherapy } \\
\text { prior to surgical resection }\end{array}$ \\
\hline $\begin{array}{l}\text { Tuhar et al. } \\
2015 \text { [10] }\end{array}$ & Lingual tumour & Total glossectomy & 1 & $\begin{array}{l}\text { Case report, } \\
\text { Romania }\end{array}$ & $\begin{array}{l}\text { Plastic } \\
\text { surgery and } \\
\text { reconstructive } \\
\text { microsurgery }\end{array}$ & $\begin{array}{l}\text { Reconstruction with free flaps } \\
\text { is feasible method of restoring } \\
\text { speech }\end{array}$ \\
\hline $\begin{array}{l}\text { Luna Ortiz } \\
\text { et al. } \\
2008[1]\end{array}$ & $\begin{array}{l}\text { Adenoid cystic } \\
\text { carcinoma of the } \\
\text { tongue (Grade III) }\end{array}$ & $\begin{array}{l}\text { Total } \\
\text { glossectomy with } \\
\text { reconstruction }\end{array}$ & 1 & $\begin{array}{l}\text { Case report, } \\
\text { Mexico }\end{array}$ & $\begin{array}{l}\text { Head and neck } \\
\text { surgery }\end{array}$ & $\begin{array}{l}\text { Speech difficulty due to the size } \\
\text { of the tumour }\end{array}$ \\
\hline
\end{tabular}




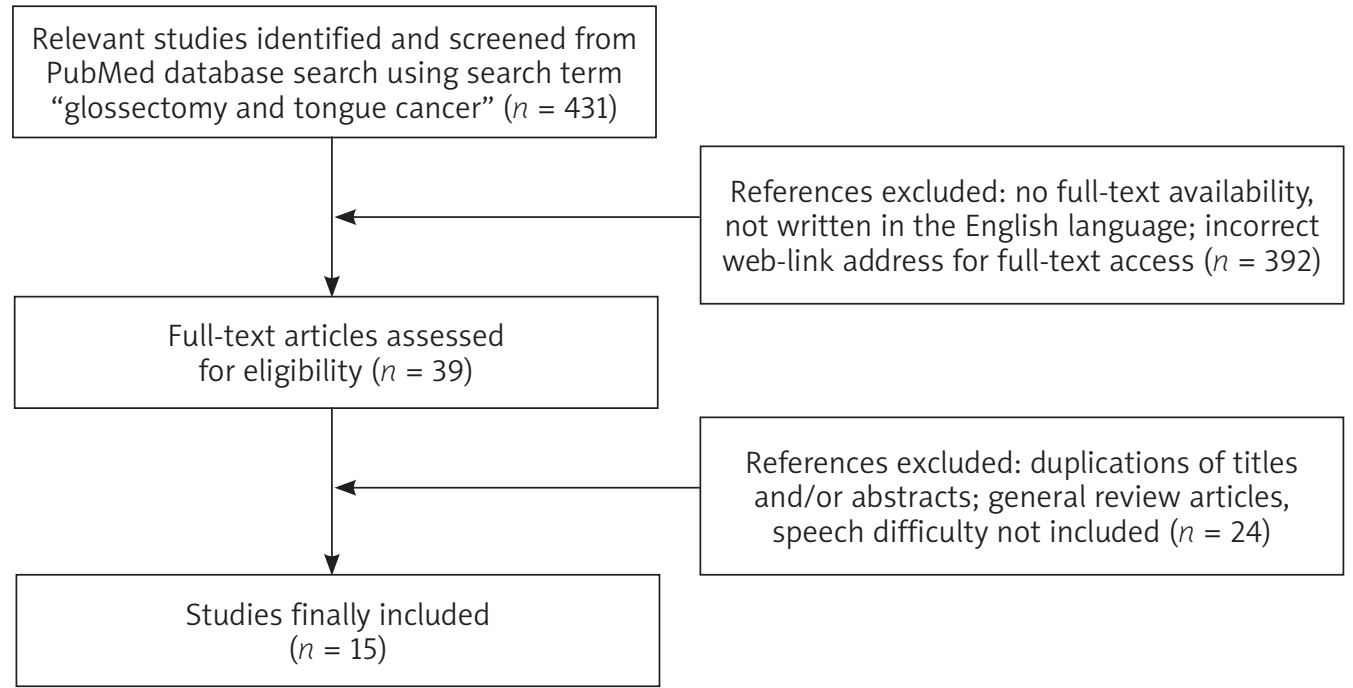

Fig. 1. Flow chart of study selection based on the inclusion and exclusion criteria

brachytherapy in tongue cancer patients mentioned that brachytherapy can limit the target volume as compared to external beam radiation, thus protecting the organ involved in speech [4]. Tasker et al. in 2005 reported a case of a total glossectomy (sparing the base of the tongue) procedure on giant haemangioma of the tongue and mentioned that the post-operative progress of the patient was good and that the patient had intelligible speech when they were discharged [5].

Parikh et al. in 1998 compared hemi-glossectomy and total glossectomy procedures on tongue cancer patients and reported a direct relationship between glossectomy procedures and considerable speech difficulties. However, there was absolutely no difference in the quality of speech between both types of surgery [6]. In the published report of Halczy-Kowalik et al. in 2012 it was mentioned that reconstruction of the tongue mass after a hemi-glossectomy (i.e. where the tongue is resected lengthwise) may be beneficial for the act of swallowing but detrimental for speech generation because of the limited mobility of the remaining part of the tongue [7]. Tarsitano et al. in 2013 compared functional results of micro-vascular free radial and antero-lateral flap surgical procedures following hemi-glossectomy in metastatic tongue cancer patients and reported that no significant differences were seen for speech intelligibility or quality of life between the two surgical-flap procedures [8]. A possible explanation of these results could be that a thinner and more pliable flap, such as FRFF, may restore speech articulation more easily than ALTF. Both more extensive surgical resection (pelvectomy) and adjuvant radiotherapy are factors predictive of worse speech intelligibility recovery. Unsworth et al. in 2013 also mentioned that partial glossectomy with micro-vascular reconstruction procedure in tongue cancer patients helped with oral functions (i.e. speech and swallowing) in the early healing period [9]. Similarly, Tuhar et al. reported that total glossectomy procedures with reconstruction flap surgery performed on advanced cancer patients was a feasible method of restoring speech [10]. The use of free flaps in the immediate reconstruction of the tongue after tumour resection should aim at the maintenance of the mobility of the residual tongue and restoration of tongue bulk in order to optimise the recovery of speech and swallowing function.

Bachher et al. evaluated effective rehabilitation approaches following partial glossectomy procedures and reported that voice quality and resonance are compromised because of a change in oral cavity volume. Articulation is affected because the tongue is unable to assume the normal position to provide valuing action needed for precise articulation. Further to this, the larger the segment of the tongue resected, the greater is the distortion of speech [11]. Sargis et al. stated that speech is believed to be determined by variables such as the extent and site of the resection in the glossectomy procedure. In other words, slight differences in tumour size dissection do not create significant differences in ability to produce speech gestures [12]. However, glossectomy patients have limited motion on the tumour-resected side and they compensate for this with greater motion on the non-tumour side in order to elevate the tongue tip $[13,14]$. Kies et al. mentioned that glossectomy patients underwent a standardised speech and swallowing evaluation before induction chemotherapy and after induction chemotherapy prior to surgical resection of the tongue, and the results were associated with excellent prognosis [15].

\section{Post-glossectomy oral cancer and speech difficulties}

Glossectomy is the surgical removal of the tongue, and it is categorised into two types, namely partial and total. Partial glossectomy is the surgical removal of the anterior two-thirds of tongue. In total glossectomy the entire tongue is surgically removed. Glossectomy is the primary treatment option for oral cancer patients with tongue involvement [41]. 
The tongue is central to the production of vowels and consonants, and the tongue volume helps to maintain resonance. The tongue and lips modulate the production of vowels or consonants due to the capacity of the oral cavity to modify its size and shape. The final speech utterance is produced through a partially or totally occluded oral cavity [42]. Any abnormality in the oral cavity will result in speech dysfunction. Total or partial removal of the tongue will result in speech articulation difficulties as well as changes in resonance [11]. Speech dysfunction may also be identified in post-surgical oral cancer cases of the tongue, floor of mouth, and soft/hard palate. Disruption of the tongue or other oral structures that are involved in speech production and articulation by a tumour or surgical intervention will affect speech intelligibility and affect patient's quality of life [8].

Speech dysfunction following glossectomy is dependent on factors such as extent of surgical resection, tumour stage, tumour site, and extent of severity of damage to tongue muscles during surgical procedure. Additional post-glossectomy complaints may include slurring of speech, gradual loss of speech, stigma or speech impediment [43].

Treatment modalities involved in post-glossectomy treatment are speech therapy, mouth and tongue stretching exercises, muscle compensation/strengthening exercises, and tongue reconstruction [44]. Post-glossectomy mouth and tongue stretching exercises, and muscle compensation exercises aid the patient by strengthening the tongue's muscles towards regaining some of the movement lost due to the glossectomy [45]. The use of maxillary prostheses aids this process as they replace hard structures like the palate and thus give the tongue a firm surface against which to produce sounds [16].

Larger surgical defect areas are usually reconstructed with flap/graft to restore normal function [46]. The effect on the intelligibility and quality of speech was more pronounced in these surgically reconstructed cases due to the reduced extensibility of the grafted tissue which may lead to decreased tongue mobility. However, additional surgical reconstruction can reverse this to a large extent.

Pre- and post-glossectomy visits to the speech pathologist are mandatory in all modalities as the Post-Glossectomy Patient (PGP) has to be re-taught the basic rudiments of speech, and once taught, they have to practice repeatedly to try and re-develop proper speech patterns. For some patients, speech therapy started 4 months after radiation treatment, and one reported that they "hit a plateau in [their] progression". Sign language as a treatment option would decrease the plateau effect by giving them another method of communication and decreasing their total reliance on speech. Speech therapists, who are not themselves fluent in sign language, can work alongside a sign linguist or a sign language teacher to include the use of sign language in therapy. This would facilitate sign language acquisition by the patient.

Despite participating in speech therapy, patients still suffer from psychological conditions caused by their loss of speech, and many report that they are more self-conscious about their post-glossectomy appearance, especial- ly where it has altered their facial appearance. One such patient reported being very self-conscious, and that knowing "people were staring at them in public" made them even more nervous. The sum effect is that these patients have lower self-esteem due to the resulting speech impediments.

In all modalities, use of a sign language is being recommended as an additional post-treatment solution for post-glossectomy patients as it will give these patients a language that they can use daily without fatigue, decrease their sole dependency on using their tongue to communicate, and it may increase their self-confidence and self-esteem. Self-confidence may increase as they do not have to communicate solely with their tongue, thus decreasing the focus on their speech difficulty by others, and thus they would be less self-conscious of their speech challenges, especially during their speech therapy phase. If at the end of the speech therapy phase they still have difficulty speaking, they can rely more on signing for communication. There can be a greater chance of fluency if sign language lessons are started once the decision to undergo the glossectomy treatment is taken. The post-glossectomy patient would be able to learn the rudiments of the language before the surgery is performed and thus be able to communicate immediately after the surgery without having to revert to written communication.

\section{Sign language as a rehabilitation tool}

A glossectomy changes the linguistic identity of a patient from oral and hearing to dysarthric and hearing for partial glossectomy patients, or mute and hearing for total glossectomy patients. This shift requires holistic pre-glossectomy preparation and support. The partial glossectomy patient would require speech therapy and may adopt a sign language as a supplemental or secondary means of communication. For the total glossectomy patient, the surgeon, psychologist and social worker should assist the patient in planning for life as a mute. This plan must include sign language acquisition which ideally would begin as soon as glossectomy is added to the treatment plan. The patient should then have sign language classes and become a member of the local Deaf community. This approach challenges the health care team to transition from a medical/pathological view of deafness to a cultural/ anthropological view. This latter view acknowledges the existence of a culture with an identity of having a visual-gestural language as its primary means of communication [47].

It may be challenging to acquire a language, particularly one in a different modality, as an adult or at the stage of life in which the patient finds himself [48]. The best teacher of a language is a native user of that language. Thus, the starting point for sign language classes should be local deaf organisations. If none are available, the patient can check schools for the deaf and religious organisations for sign language classes. Some universities offer sign language courses and programmes. If one is uninterested in an entire university programme, one may be able to audit a course or be specially admitted for a specific course. 
Members of the family or primary home support network should also learn sign language, preferably at the same time as the patient. Together, the patient and his family or support network must create a post-glossectomy communication plan. This plan would outline or detail the settings and communicative events in which speech and sign language would be used. Creating this plan would assist everyone involved in making a mental shift toward the impending speech disorder [17].

\section{Conclusions}

Post-glossectomy oral cancer patients who incorporate learning sign language in their rehabilitation are able to compensate for their speech loss, communicate more easily, improve their self-esteem, and have a higher quality of life. Oral cancer patients who undergo glossectomies require speech rehabilitation procedures to maintain in terpersonal communication because of the role of speech in social interaction. Any impairment in speech may lead to marginalisation due to social stigmas.

Sign language acts as an adjunct method of communication rehabilitation in post-glossectomy patients. In the post-operative period, compromised tongue tissue causes a reduction in the ability of patients to manipulate the tongue for well-formed phonetic articulation. The speech therapist and sign linguist can work together to create both a sign language learning plan for the patient and a communication plan that incorporates their understanding of speech with their use of sign language.

Communicating is critical to survival and a high quality of life. Whilst post-treatment speech rehabilitation may not lead to functional or complete restoration of speech, sign language as a communication method can be a tool to optimise the patient's quality of life. The incorporation of sign language use in the management of the glossectomy patient would be a novel and important step in the new drive towards comprehensive management of surgical patients.

The authors declare no conflict of interest.

\section{References}

1. Luna Ortiz K, Carmona Luna T, Herrera Gomez A, Cano Valdez AM. Macroglossia caused by adenoid cystic carcinoma. Case report. Med Oral Patol Oral Cir Bucal 2008; 13: E395-7.

2. Bell D, Kupferman ME, Williams MD, Rashid A, El-Naggar AK. Primary colonic-type adenocarcinoma of the base of the tongue: a previously unreported phenotype. Human Pathol 2009; 40: 1798-802.

3. Murano EZ, Shinagawa H, Zhuo J, Gullapalli RP, Ord RA, Prince JL, et al. Application of diffusion tensor imaging after glossectomy. Otolaryngol Head Neck Surg 2010; 143: 304-6.

4. Mazeron R, Fenoll L, Mathieu MC, Dumas I, Haie-Meder C. Brachytherapy for isolated tongue metastasis of renal clear cell carcinoma. Eur Ann Otorhinolaryngol Head Neck Dis 2013; 130: 149-51.

5. Tasker LJ, Geoghegan J. Giant cavernous haemangioma of the tongue. Anaesthesia 2005; 60: 1043.

6. Parikh HK, Rao RS, Sukhthankar P, Deshmane VH, Parikh DM. Surgery in early cancer of the oral tongue (TI-2). Wide excision versus hemiglossectomy. Indian J Otolaryngol Head Neck Surg 1998; 50 : 349-53.

7. Halczy-Kowalik L, Sulikowski M, Wysocki R, Posio V, Kowalczyk R, Rzewuska A. The role of the epiglottis in the swallow process after a partial or total glossectomy due to a neoplasm. Dysphagia 2012; 27: 20-31.

8. Tarsitano A, Vietti MV, Cipriani R, Marchetti C. Functional results of microvascular reconstruction after hemiglossectomy: free anterolateral thigh flap versus free forearm flap. Acta Otorhinolaryngol Ital 2013; 33: 374-9.

9. Unsworth JD, Baldwin A, Byrd L. Systemic lupus erythematosus, pregnancy and carcinoma of the tongue. BMJ Case Rep 2013; 2013: pii: bcr2013008864.

10. Tuhar, Zamfirescu D, Gheorghita C, Slavescu D, Frunza A, Lascar I. Ablation of advanced tongue cancer and mobile tongue reconstruction by using a sensitive anterolateral thigh and vastus lateralis muscle free flap. J Med Life 2015; 8: 64-7.

11. Bachher GK, Dholam K, Pai PS. Effective rehabilitation after partial glossectomy. Indian J Otolaryngol Head Neck Surg 2002; 54: 39-43.

12. Ananian SG, Gvetadze SR, Ilkaev KD, Mochalnikova VV, Zayratiants GO, Mkhitarov VA, Yang X, Ciciashvili AM. Anatomic-histologic study of the floor of the mouth: the lingual lymph nodes. Jpn I Clin Oncol 2015; 45: 547-54.

13. Stone M, Langguth JM, Woo J, Chen H, Prince JL. Tongue motion patterns in post-glossectomy and typical speakers: a principal components analysis. J Speech Lang Hear Res 2014; 57: 707-17.

14. Stone M, Woo J, Zhuo J, Chen H, Prince JL. Patterns of variance in /s/ during normal and glossectomy speech. Comput Methods Biomech Biomed Eng Imaging Vis 2014; 2: 197-207.

15. Kies MS, Boatright DH, Li G, Blumenschein G, El-Naggar AK, Brandon Gunn G, et al. Phase II trial of induction chemotherapy followed by surgery for squamous cell carcinoma of the oral tongue in young adults. Head Neck 2012; 34: 1255-62.

16. Vieira CA. Speech therapy in total glossectomy - case study. Rev Soc Bras Fonoaudiol 2011; 16: 4.

17. KC. Caribbean Sign Language for Dentistry: A Guide to Communicating with Deaf Patients for Dental Practitioners. HIS Publishing; Tacarigua: 2014.

18. Chung TK, Rosenthal EL, Magnuson JS, Carroll WR. Transoral robotic surgery for oropharyngeal and tongue cancer in the United States. Laryngoscope 2015; 125: 140-5.

19. Saxena VS. Cancer of the tongue: local control of the primary. Cancer. 1970; 26: 788-94.

20. Tomioka T, Hayashi R, Ebihara M, Miyazaki M, Shinozaki T, Fujii S. Observation as an option for epithelial positive margin after partial glossectomy in stage I and II squamous cell carcinoma: analysis of 365 cases. Jpn I Clin Oncol 2013; 43: 520-3.

21. Ando M, Asai M, Asakage T, Oyama W, Saikawa M, Yamazaki M, et al. Metastatic neck disease beyond the limits of a neck dissection: attention to the 'para-hyoid' area in T1/2 oral tongue cancer. Jpn J Clin Oncol 2009; 39: 231-6.

22. Ganly I, Goldstein D, Carlson DL, et al. Long-term regional control and survival in patients with "low-risk," early stage oral tongue cancer managed by partial glossectomy and neck dissection without postoperative radiation: the importance of tumor thickness. Cancer 2013; 119: 1168-76.

23. Urashima Y, Nakamura K, Kunitake N, Shioyama Y, Sasaki T, Ooga S, et al. Is glossectomy necessary for late nodal metastases without clinical local recurrence after initial brachytherapy for NO tongue cancer? A retrospective experience in 111 patients who received salvage therapy for cervical failure. Jpn I Clin Oncol 2006; 36: 3-6.

24. Akhtar S, Ikram M, Ghaffar S. Neck involvement in early carcinoma of tongue. Is elective neck dissection warranted? J Pak Med Assoc 2007; 57: 305-7.

25. Ikram M, Jafferbhoy SF, Onali MA. Neck recurrence in early carcinoma tongue. J Pak Med Assoc 2006; 56: 448-51.

26. Habu N, Imanishi Y, Kameyama K, Shimoda M, Tokumaru Y, Sakamoto K, et al. Expression of Oct3/4 and Nanog in the head and neck squamous carcinoma cells and its clinical implications for delayed neck metastasis in stage I/II oral tongue squamous cell carcinoma. BMC Cancer 2015; 15: 730. 
27. Lopez de Cicco R, Watson JC, Bassi DE, Litwin S, Klein-Szanto AJ. Simultaneous expression of furin and vascular endothelial growth factor in human oral tongue squamous cell carcinoma progression. Clin Cancer Res 2004; 10: 4480-8.

28. Shiga K, Ogawa T, Sagai S, Kato K, Kobayashi T. Management of the patients with early stage oral tongue cancers. Tohoku J Exp Med 2007; 212: 389-96.

29. Pugazhendi SK, Thambiah L, Venkatasetty A, Thangaswamy $V$. Elective neck dissection versus "wait and watch" policy in tongue carcinoma. J Pharm Bioallied Sci 2012; 4 (Suppl 2): S226-9.

30. Pons Y, Gauthier J, Clement P, Conessa C. Ultrasonic partial glossectomy. Head Neck Oncol 2009; 1: 21.

31. Saito T, Den S, Hiraga K, Uchiyama K, Carlsson C. The difference between delayed extubation and tracheostomy in post-operative sleep apnea after glossectomy or laryngectomy. Jpn J Clin Onco 1999; 29: 127-31.

32. Esmati E, Babaei M, Matini A, Ashtiani MS, Hamed EA, Nosrati H, et al. Neuroendocrine carcinoma of the tongue. J Cancer Res Ther 2015; 11: 659.

33. Tanaka Y, Tomifuji M, Suzuki H, Yamashita T, Araki K, Shiotani A. Transoral videolaryngoscopic surgery with a navigation system for excision of a metastatic retropharyngeal lymph node. ORL J Otorhinolaryngol Relat Spec 2014; 76: 357-63.

34. Abrari A, Bakshi V. Solitary fibrous tumour (SFT) of the residua tongue, post partial glossectomy for carcinoma. Ind J Pathol Mi crobial 2014; 57: 648-50.

35. Preetam C, Sikka K, Kumar R, Kumar R. Always expect the unexpect ed - chyle leak: revisiting the entity. Indian J Cancer 2013; 50: 8.

36. Crede A, Locher M, Bredell M. Tongue cancer in young patients: case report of a 26-year-old patient. Head Neck Oncol 2012; 4: 20.

37. Irfan M, Aliyu YA, Baharudin A, Shahid H. Harmonic scalpel fo a bloodless partial glossectomy: a case report. Med J Malaysia 2011; 66: 148-9.

38. Deshmukh M, Bal M, Deshpande P, Jambhekar NA. Synchronous squamous cell carcinoma of tongue and unicentric cervical Cas tleman's disease clinically mimicking a stage IV disease: a rare association or coincidence? Head Neck Pathol 2011; 5: 180-3.

39. McNamara K, Olaleye O, Smith J, Karamchandani D, Watkinson J. A rare case of a concurrent large thyroglossal duct cyst with a base of tongue haemangioma. BMJ Case Rep 2011; 2011: pii: bcr1020103393.

40. Bhojraj S, Jain S, Hamdulay Z, Kumar P, Ali M, Pradhan S. Simultaneous off-pump coronary artery bypass graft surgery and wide glossectomy. Ann Card Anaesth 2008; 11: 46-8.

41. OW TJ, Myers JN. Current management of advanced resectable oral cavity squamous cell carcinoma. Clin Exp Otorhinolaryngol 2011; 4: 1-10.

42. Laver J. The architecture of phonetic classification. Principles of Phonetics. Cambridge University Press, Cambridge 1994; 119-58.

43. Chuanjun C, Zhiyuan Z, Shaopu G, Xinquan J, Zhihong Z. Speech after partial glossectomy: a comparison between reconstruction and nonreconstruction patients. J Oral Maxillofac Surg 2002; 60: 404-7.

44. Pauloski BR. Rehabilitation of Dysphagia Following Head and Neck Cancer. Phys Med Rehabil Clin N Am 2008; 19: 889-928.

45. Furia CL, Kowalski LP, Latorre MR, Angelis EC, Martins NM, Barros AP, Ribeiro KC. Speech intelligibility after glossectomy and speech rehabilitation. Arch Otolaryngol Head Neck Surg 2001; 127: 877. 883.

46. Mazarro A, de Pablo A, Puiggròs C, Velasco MM, Saez M, Pamias J, Bescós C. Indications, reconstructive techniques, and results for total glossectomy. Head Neck 2016; 38 (Suppl 1): E2004-10.

47. Cumberbatch K. Deaf culture. Caribbean Sign Language for Dentistry: A Guide to Communicating with Deaf Patients for Dentists. HIS Publications: Tacarigua, 2014. E-book with Film.

48. Mckee RL, McKee D. What's so Hard about learning ASL?: students' and teachers' perceptions. Sign Language Studies 1992; 75 $129-58$

\section{Address for correspondence \\ Arvind Babu Rajendra Santosh}

Oral and Maxillofacial Pathologist,

Lecturer and Research Coordinator - Dentistry Programme

Faculty of Medical Sciences

The University of the West Indies Mona Campus,

Kingston 7 Jamaica, West Indies

e-mail: arvindbabu2001@gmail.com

Submitted: 15.12 .2016

Accepted: 24.01.2017 